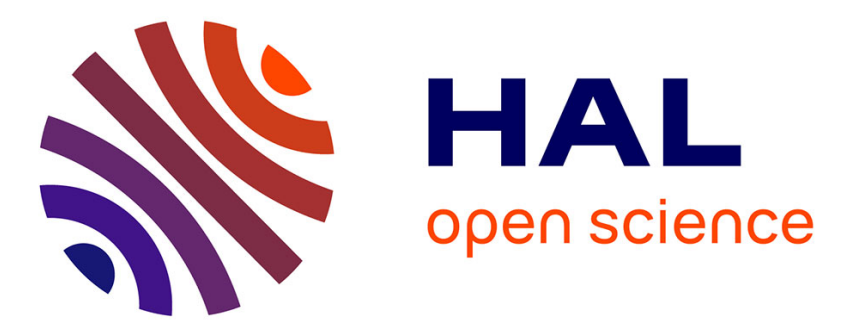

\title{
Transitions - news on the access to digital information in France
}

Joachim Schöpfel

\section{To cite this version:}

Joachim Schöpfel. Transitions - news on the access to digital information in France. Interlending and Document Supply, 2003, 32 (1), pp.47-49. 10.1108/02641610410520260 . sic_00000947

\section{HAL Id: sic_00000947 \\ https://archivesic.ccsd.cnrs.fr/sic_00000947}

Submitted on 23 Mar 2004

HAL is a multi-disciplinary open access archive for the deposit and dissemination of scientific research documents, whether they are published or not. The documents may come from teaching and research institutions in France or abroad, or from public or private research centers.
L'archive ouverte pluridisciplinaire HAL, est destinée au dépôt et à la diffusion de documents scientifiques de niveau recherche, publiés ou non, émanant des établissements d'enseignement et de recherche français ou étrangers, des laboratoires publics ou privés. 


\section{Transitions - news on the access to digital information in France}

\section{Foachim Schöpfel}

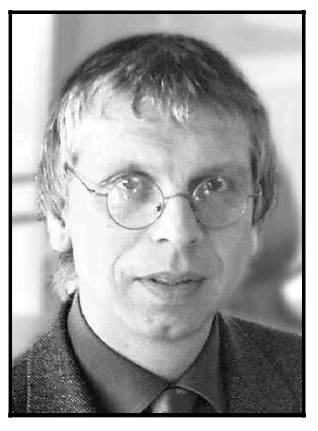

The author

Joachim Schöpfel is Head of the Library Department of INIST-CNRS and Lecturer at the Nancy University, Nancy, France.

\section{Keywords}

Document delivery, Copyright law, Portals, France

\section{Abstract}

The author describes the present document delivery situation in France with particular reference to copyright and the EU Directive, consortia, portals, funding and some suggestions for the future.

\section{Electronic access}

The Emerald Research Register for this journal is available at www.emeraldinsight.com/researchregister

The current issue and full text archive of this journal is available at

www.emeraldinsight.com/0264-1615.htm

Interlending \& Document Supply

Volume $32 \cdot$ Number $1 \cdot 2004 \cdot$ pp. 47-49

(C) Emerald Group Publishing Limited · ISSN 0264-1615

DOI 10.1108/02641610410520260

\section{Copyright}

Up to October 2003, the French Government had not implemented the European Directive of 2001. The announced draft law has not been submitted to the Parliament yet, and one can only speculate about the implementation date (Spring, 2004?). All we know of is an initial draft law from December 2002 and an unofficial second version dated April 2003 where the "educational exception" for the benefit of teaching and scientific research has disappeared (see Marzouki, 2003). In spite of protestations from the presidents of the French universities, the government seems not to intend to (re)introduce this exception into the transposition. The future law will probably reinforce the author's (and publisher's) rights and will be rather restrictive for the end user (private copy, teaching, research, corporate sector).

Nevertheless, the European Directive already affects the access to scientific information in France. Three days after the draft implementation of the new German copyright law (13 September), the Subito and GBV network shut down the document supply to commercial and private customers in France. The forthcoming UK copyright act (March, 2004?) drives the French customers of the British Library services to reconsider their relationship with the worldwide most important document supplier. It is not clear how, or when, other channels of document delivery (CINDOC, CISTI, other European libraries or networks) will be affected by this evolution.

Probably, French customers have to anticipate higher prices and copyright fees and more complicated document supply. Nevertheless, it is too soon to know if the effect of this will be to increase the cost of document delivery to all sectors, i.e that publishers will be able to charge copyright fees to commercial as well as academic customers. Meanwhile, INIST-CNRS has started negotiations with publishers. On the agenda are access to information and electronic delivery. The position of the French academic interlibrary lending (ILL) system (PEB) seems uncertain. 
Transitions - news on the access to digital information in France

Joachim Schöpfel

\section{Consortial purchasing}

In May 2003, the research and education ministries decided to create a large national consortium. This new public structure Groupement d'Intérét Public (GIP) should cover the whole sector of higher education and public research from 2005 on. The preparation of the future structure is in progress but will take time (> 18 months), as several points need thorough reflection and coordination (funding, decision structures, procedures, archives etc.).

For 2004, the academic consortium COUPERIN continues to negotiate licences with the main scientific publishers. The two public research organizations, CNRS and INSERM, operate a joint purchasing scheme of access to $2000+$ electronic journals and databases for more than 11,000 researchers in the medical and life sciences sector via two INIST portals.

\section{Portals}

How can researchers keep up with the growing number and heterogeneity of electronic resources? How can access and rights management be facilitated to these resources? Three options can be identified, each of them responding to specific needs. Some recent examples are:

- General portals. Following the success of the two CNRS portals for the French scientific community (ConnectSciences and BiblioSciences), the bibliographic agency ABES has prepared another portal for the HE sector, a single access to digital resources (serials, theses, databases) linked to the national union catalogue SUDOC and the ILL service.

- Specific portals. Last year, INIST created a portal for the French medical research organization INSERM (5,000 researchers) that allows access to medical journals and databases. Two others portals are in development: a portal in life sciences for 6,000 researchers in nearly 400 CNRS laboratories and another portal in social sciences and humanities which will integrate free and reserved access to serials, monographs, databases and other information services.

- E-publishing. With public funding from the French education ministry, a consortium led by Nice University is working on a portal for the online access to the digital archives from French serials in social sciences. INIST has developed a platform for French learned societies and other scientific publishers who want to go online (social sciences and humanities).

\section{Document supply}

The relative decline of the traditional document supply by ILL or delivery of paper copies continues. The main reasons are known (see Schöpfel, 2003). In addition, the current French economic environment - reduction in research funding, industrial recession - does not favour the demand of scientific and technical information. In this situation, INIST decided to restructure its commercial activities and to enhance cooperation with other major suppliers. Nevertheless, the objective remains unchanged: to guarantee the access to scientific information for the French public research and the corporate sector.

One way to do so is through open archives. After having co-organized the first international conference on this topic in France in January 2003 (see Battisti, 2003), INIST contributes to the French debate (www.inist.fr/openaccess), enhances its cooperation with the French centre of direct scientific communication at Lyon (http://ccsd.cnrs.fr), contributes to the Max-Planck Conference on Open Access, at Berlin (www.zim.mpg.de/openaccess-berlin/ index.html) and sponsors the 5th International Conference on Grey Literature at Amsterdam (www.textrelease.com) where the question of open access to scientific information will be one of the main topics.

\section{Public funding}

The high public deficit in France affects document supply and access to scientific information. Public funding of documentation 
Transitions - news on the access to digital information in France

Joachim Schöpfel

is spread between several ministries and administrations (research, higher education, culture, health, etc.) and there is no real national coordination or information policy; there is no French equivalent of the UK Joint Information Systems Committee for Higher Education. Two economic models are in concurrence:

(1) a "multilateral financing model" where public administration, organization (university) and end user (laboratory) share the costs ("COUPERIN model"); and

(2) a "central funding model" where the administration and/or organization pays the whole price, with free access for the end user (“CNRS/INSERM model”).

But what is the real price of access? Licences shift from the "paper past" to the real account of number of potential users. Here, the complex organization of French public research (often research staffs from two or more organizations are working on the same site) creates a supplementary difficulty for pricing and tends to penalize the funding bodies. In the future, reliable usage statistics may facilitate the negotiation for a just price of access to electronic information.

\section{Preparing the future}

Some months ago, the French information industry lobby GFII initiated working groups on serials subscriptions and content acquisition in order to enhance cooperation between publishers, agencies, libraries and documentation centres (www.gfii.asso.fr). This may result in a public marketplace of digital information in France, perhaps also in the creation of a French serials group. One stepping stone to this market place will be the 2 nd I-Expo Conference and Exposition on Digital Information, at Paris, in June 2004 (www.i-expo.net); the director of INIST, R. Duval, chairs the programme committee.

These are transitions to an uncertain future, and there is nothing definite. But let us predict three options for the next months: first, the small number of public institutions able to manage access to digital information will continue to suffer from low budgets and political deficit. Second, different models of access will coexist (instead of one emerging model) even if the importance of information supply for specific scientific communities will increase, and third, there will be a widening gap of document supply between the private and the academic sector.

\section{Post-script}

On November 12, the French Minister of Culture and Communication, J.J. Aillagon, finally presented the draft of the future "law on author's and related rights in the information society" to the Government (see www.culture.gouv.fr). As expected, this draft reinforces the author's rights and contains only two exceptions (private copy, handicapped people) without any "educational exception". The law should be submitted to the Parliament in the first half of 2004 .

\section{References}

Battisti, M. (2003), "Libre accès à l'information scientifique et technique: état de l'art et perspectives", Documentaliste, Vol. 40 No. 1, pp. 37-45.

Marzouki, M. (Ed.) (2003), "France", in Implementing the UE Copyright Directive,Foundation for Information Policy Research, pp. 55-69, available at: www.fipr.org/ copyright/guide

Schöpfel, J. (2003), "INIST-CNRS in Nancy, France: 'a model of efficiency'", Interlending \& Document Supply, Vol. 31 No. 2, pp. 94-103. 